\title{
THE DYNAMICS OF HONG KONG'S OFFICE RENTAL MARKET
}

\author{
Eddie Chi Man HUI and Ka Hung YU \\ Department of Building and Real Estate, The Hong Kong Polytechnic University, Hunghom, \\ Kowloon, Hong Kong, China \\ Fax: (852) 2764 5131, E-mail: bscmhui@inet.polyu.edu.hk
}

Received 24 November 2005; accepted 10 February 2006

\begin{abstract}
Forecasting office rents is among the most researched topics in real estate study. However, there are still heated debates on how predictions can be best done. This study provides a generator approach, on the basis of both system dynamics and econometric modeling. The findings suggest that the office rental values in Hong Kong appear to be more volatile and uncertain under better economic conditions, likely due to both the supply side of the property market being over-optimistic of economic trends and the development lags and adjustment cost, under the influence of the current land policies in Hong Kong, are the main issues behind this phenomenon. In order to minimize the uncertainties on the office leasing market, the government should relax the approval procedures concerning changing land use, and the subsequent rearrangements of premium payment. Further, the current policies on land sales need to be revised, especially the application list system. Those measures could reduce the time and transaction cost incurred, thus leading to more timely response to demand changes over time.
\end{abstract}

KEYWORDS: Office Rental Values; System Dynamics Modeling; Econometric Modeling; Hong Kong

\section{INTRODUCTION}

To evaluate the competitiveness of a city as a business (or financial) centre, one of the major determinants is whether its office rental values can compete with other cities. Hong Kong has become a business centre for foreigners to have business relationships with Mainland China. In Hong Kong, office rents are actually comparable to those in cities like Beijing, Shanghai, and Singapore (Jones Lang LaSalle, 2003). Hong Kong's economy has encountered two serious demand shocks in the past several years. Figure 1 illustrates the price/rental adjustments of Class A offices from 1993 to 2003.
During the time when Hong Kong was under the attack of the SARS epidemic, the office rental value has dropped by $15.73 \%$ from March to June 2003 and a remarkable $23.66 \%$ decline in Class A office rents in 2003 (Chesterton Petty, 2004). The vacancy rate remained double-digit in the same year. Hong Kong has become one of the most competitive major cities in the world, in terms of total business cost per employee.

With SARS' ramifications gradually reduced and the newly found competitiveness on the office leasing market, combined with China's entry to the World Trade Organization (WTO) and the signing of the Closer Economic Partnership Arrangement (CEPA) between Hong

International Journal of Strategic Property Management

ISSN 1648-715X print / ISSN 1648-9179 online @ 2006 Vilnius Gediminas Technical University

http://www.ijspm.vgtu.lt 
Kong and the Mainland, it is expected that office demand would be recovered in the near future. There would be an expected increase of $3.3 \%$ in office rent in the $1^{\text {st }}$ quarter of 2004 , and about 5-10\% rise in office rent in the next 12 months (Hang Seng Property Market Trends, 2005).

The aim of this paper is to simulate the dynamics of rental adjustments of office spaces in Hong Kong under certain scenarios representing different economic conditions. The selection of Hong Kong is because it is generally considered one of the most vibrant commercial/financial centers in Asia, probably in the world. It was especially the case with the occurrence of events in the last decade such as the handover to China, the Asian Financial Crisis, and the SARS epidemic. Hong Kong's association with Mainland China could induce a lot of new economic opportunities to Hong Kong. Within the local context, Hong Kong has one of the most extensive land policies in the world. For instance, an application list system is currently used. It requires developers to offer a price considered good enough, based on the government's own valuations, before a piece of land could be put on sale via an auction. Also, if developers decide to increase sup- ply of properties through other forms such as redevelopment, a premium has to be paid to the government before the project takes place, not to mention the various decrees regulating the density, heights, land use, etc. A combination of the above two situations could induce a complicated, yet interesting, dynamic on the Hong Kong office market. The hypothesis in this paper is that various forms of land policies would help create a volatile, yet relatively uncertain, office market. By looking at the dynamics of rental values in Hong Kong, this paper intends to fill in the knowledge gap by introducing a generator approach, which is based on the ideas of system dynamics and conventional econometrical models, in attempt to capture the possible future office rental trends.

This paper is divided into four sections. Firstly, a literature review provides the work done by previous studies on forecasting the trends of commercial real estate values and returns, setting up the foundation and focus of this study. Then, the methodology and data section provides a general picture of the framework used for the study. In the third section, results from the model are presented and analyzed. The last section concludes the study.

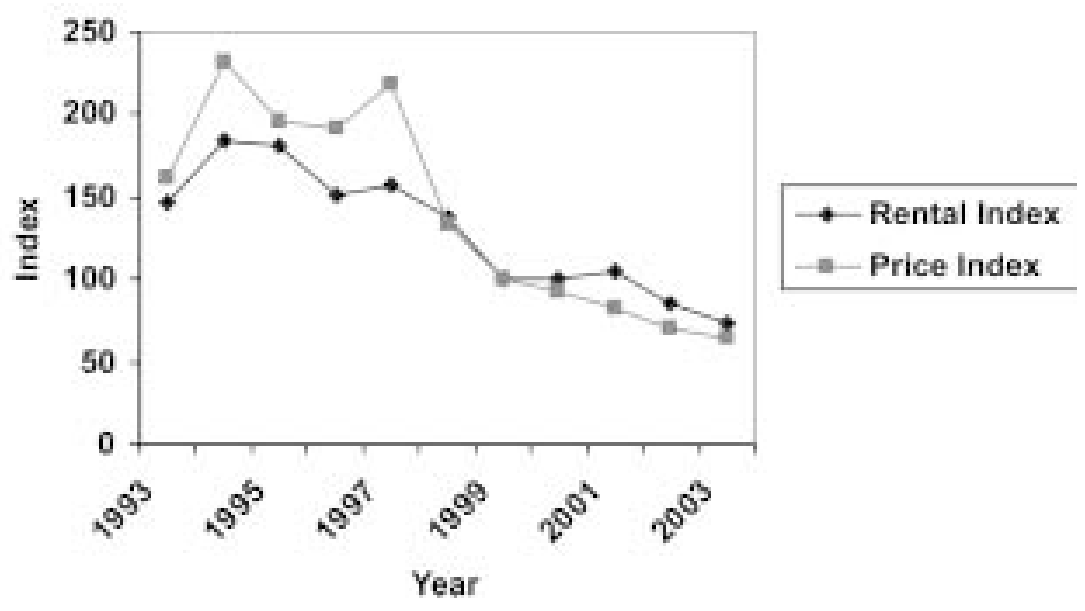

Figure 1. Office Price \& Rental Indices (Source: Rating \& Valuation Department) 


\section{LITERATURE REVIEW}

Forecasting future office rental trends is among the most researched topics in real estate studies. However, it was argued that earlier approaches in estimating rental growth rates in discounted cash flow valuation exercises are often overly simplistic, which leads to unrealistic projections (Hendershott, 1996; Born \& Pyhrr, 1994). It was also found by Kummerow (1997) that Australian valuers commonly adopted a single, linear and compounding rent growth rate in their assessments during the 1980s. A study conducted by Cowley (2003), on valuers in Brisbane, Australia, found that broad cyclical rent forecasts were used by most valuers in cash flow studies, but it appeared to lack a methodology and fortitude in recognizing the volatility of the property market, due to the conservative nature of forecasts in this city.

As there are situations where weaknesses are observed in regressions and trend forecasting, well-calibrated structural models such as system dynamics simulators can perform reasonably well in forecasting (Sterman, 1988; Sterman, 2000; Lyneis, 2000). Structural modeling for forecasting purposes have been used, from understanding America's urban crisis (Forrester, 1969) to dynamics of the housing market from the perspective of housing associations' (Vennix, 1996). Within the context of Hong Kong, Hu and Shan (2000) make use of system dynamics in simulating the urban housing development in Hong Kong. But in general, studies under such structure are relatively few.

According to Forrester (1992), the uniqueness of system dynamics over regular regression models is that "symptom, action, and solution are not isolate in a linear cause-and-effect relationship, but exist in a nest of circular and interlocking structures. In such structures an action can induce not only correction but also fluctuation, counter-pressures, and even accentuation of the very forces that produced the original symptoms of distress." A system dynamics framework provides a means of understanding the causes of industry behavior, and the determination of factors, to which forecast behavior are significantly sensitive, is allowed to be detected earlier. Further, system dynamics models allow the determination of reasonable scenarios as inputs to decisions and policies (Tonelli, Cowley and Boyd, 2004).

Regarding the factors used on previous office rental market researches, McGough and Tsolacos (1995) selected demand side factors such as GDP and employment growth, to examine commercial building activity in the UK and its procyclicality. The impact of economic fundamentals on building vacancy rates as a generator of property cycles was examined by Canter, Gordon and Mosburgh (1996). Grissom and DeLisle (1999) commented that the relationship between macroeconomic variables and the property market provide the ability to distinguish between the different stages of real cycles when looking at property returns. Another survey conducted by McDonald (2002) on office market econometric models focused on the models developed by Wheaton, Torto and Evans (1997) and Hendershott, Lizieri and Matysiak (1999). The DiPasquale/Wheaton (1996) - Wheaton/Torto/Evans models incorporate the majority of the explanatory variables found to be dominant in the many models that have evolved over time.

In general, the dominant property/market determinants adopted for office rents include observed and natural vacancy rates and space supply, in addition to historical or observed rents. The prevalent economic/financial determinants adopted include economic activity, interest rates and employment (Tonelli, Cowley, and Boyd, 2004).

\section{METHODOLOGY AND FRAMEWORK}

This paper presents a two-stage generator framework on the determination of the office rental movements in Hong Kong. Firstly, a multiple regression model is depicted as the main feature of the framework in this study. 
After that, such model will be put into a system dynamics structure in order to portray the dynamic conditions of Hong Kong's office rental market. The use of the system dynamics structure is due to several advantages it has over conventional statistical models (Tonelli, Cowley and Boyd, 2004). Firstly, usual analyses are static in nature, which do not take the changing dynamics of the market environment into consideration. Meanwhile, a system dynamics model takes the interaction of different variables into account, which consequently induces changes overtime. Lyneis (1999) shares similar viewpoints about the usefulness of system dynamics modeling, as more reliable forecasts of short- to mid-term trends can be provided by system dynamics models than statistical models, thus leading to better decisions. It suits well with the dynamic, vibrant nature of Hong Kong's economy and its office market.

Office rental movements are the results of the adjustments of the demand and supply of office space over time. Therefore, both demand side and supply side elements will be injected into the model, aiming at capturing the dynamics of the demand/supply situations of the office rental sector. On the demand side, the change in the Consumer Price Index (CPI) is selected for the study, which is considered the representation of the general price movements in Hong Kong. This is primarily the indicator for the price movements of consumer goods in general. The best lending rate (or the interest rate) is essentially the cost of capital for businesses, which can be utilized as a measuring stick to compare with the expected return of starting up a business, thus shaping the demand for office spaces (see D'Arcy et. al., 1997). GDP growth rate reflects the general economic performance in a particular period of time, compared to that of a preceding period. A positive rate indicates that the economy is performing well, which is a catalyst for further production of goods and services due to the sustainable demand (see Giussani et. al., 1993; Tsolacos et. al., 1998; D’Arcy et. al., 1999).

It is worth noting that the Finance, Insur- ance and Real Estate (FIRE) sector unemployment rate, instead of the general unemployment rate, is selected for this study. Many studies (Armstrong, 1979; Wheaton, 1987; Pollakowski et al. 1992; Clapp, 1993; Howland and Wessel, 1994; DiPasquale and Wheaton, 1995; Liow, 2000; Jayantha and Ganesan, 2002) have suggested that the services sector, especially the FIRE sector, has been the major source of demand for office space in the economy. For years, the FIRE sector has accounted for around 20-27 \% of Hong Kong's GDP (C\&SD, 2005). Due to the increasing importance of the FIRE sector to Hong Kong's economy, the real wage index of the FIRE sector has been included in the model as well. The real wage index of the FIRE sector provides a good reflection of the productivity of labour over the years. Another indicator, called the Export of Service (EOS) index, is selected for the model, as this figure describes the income generated from the provision of service to foreign countries. It is assumed that a higher EOS Index suggests a higher level of demand for Hong Kong's service, thus indirectly expanding the demand for office space from companies which offer such service.

On the supply side, four variables are used in the study. Office stock (in meter. square) illustrates the general supply situations of office space in an area. As a higher level of office stock suggests a higher level of supply, a negative impact is expected to occur in the rental value of office space. Vacancy rate indicates the discrepancies of demand and supply conditions of office space. The yield rate essentially shows the income-earning ability of office space in the rental market. A higher yield rate insinuates a higher rental level, given a constant office price level. It is expected a higher yield rate encourages more supply on the office rental market, while a higher relative price level on the office rental market could reduce the demand for office space. Lastly, the forecast supply (in meter. square) is the estimated amount of new office space supplied in the year after, provided by official data, which 
in perspective can tell us about the anticipations of the provision of office floor space in the future.

The aforementioned data is gathered from the Census \& Statistics Department in Hong Kong (general economic indicators such as GDP, FIRE sector unemployment rate, etc), the Rating \& Valuation Department (office rents, yield rates, vacancy rates, and office stocks, forecast supply), and HSBC (best lending rate) during the period 1990:1-2004:4. The rental values, vacancy rates, yield rates, office stocks, and forecast supply are the figures of Class A Offices in Central. The amount of Class A office stocks in Central is about $40 \%$ of the to- tal Class A office stocks available in Hong Kong Island, and more than $25 \%$ of the total Class A office stocks available in Hong Kong (Rating \& Valuation Department, various issues). It is believed that price/rental movements in Central's offices are good indicators of such movements in Hong Kong. Lastly, it should be noted that due to data limitations, data on office stock, vacancy rate, and the forecast supply are assumed to be constant on a yearly basis.

A structure map is illustrated in Figure 2, showing the mechanism of the multiple regression model and the interactions between office rental level and the selected variables.

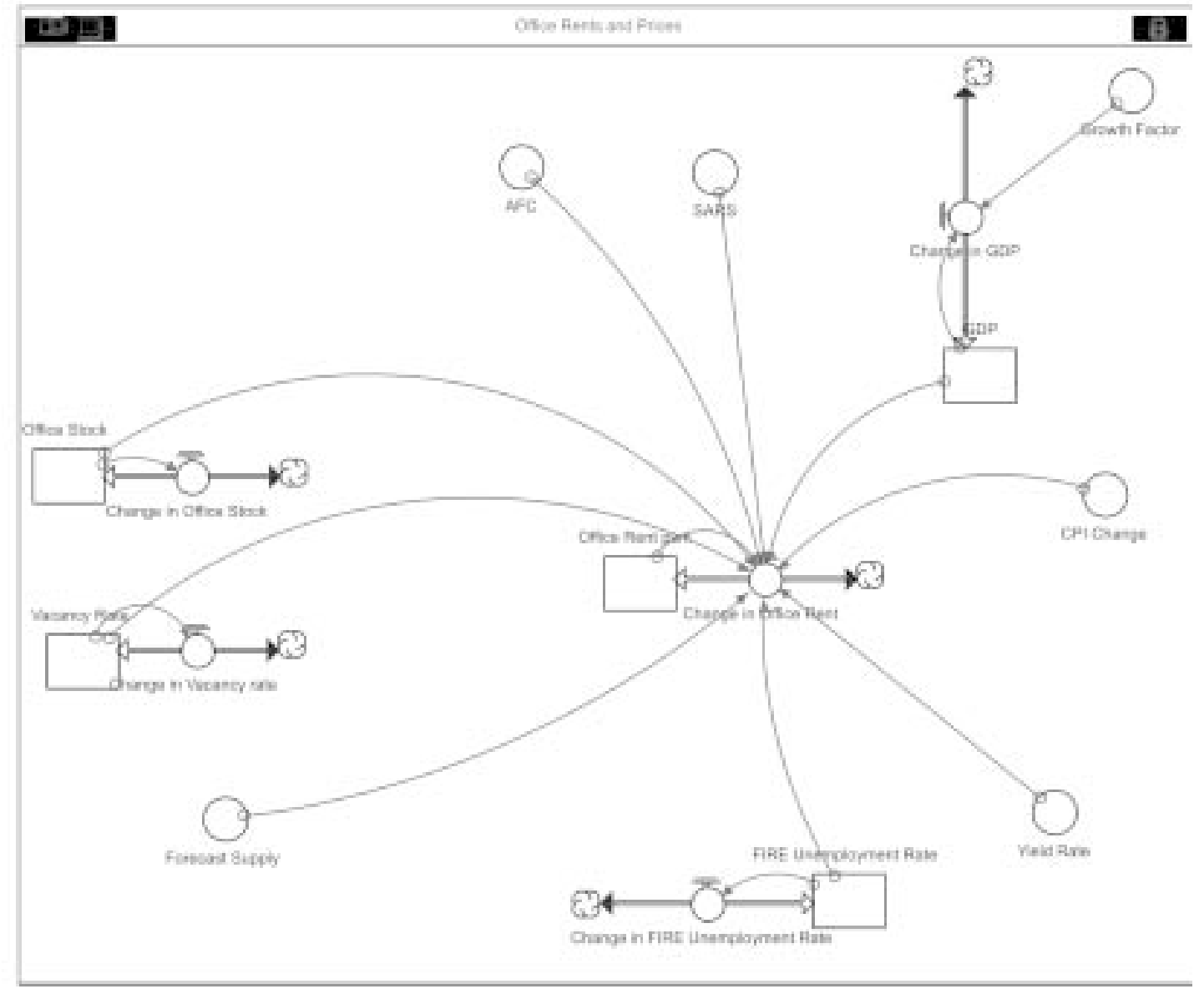

Figure 2. Conceptual map of the multiple regression model presented in the first stage of the study 
Static Modeling:

A multiple regression model is introduced, as the foundation of the whole dynamic system. The final model is selected from two alternative models, which the primary difference is the methods used to detect the possible lead/ lag relationships between office rental level and the variables discussed in paragraphs above. One of such is based on the results from the Granger Causality tests, while the other is based on the results from the Cross-correlation tests. (For more details, please refer to the Appendix).

The regression model is illustrated by the following equation:

$$
\begin{aligned}
& \text { ORt }=a 1+a 2 * \text { OSt }+a 3 * V R t-4+ \\
& a{ }^{*} \text { FIREUR }-1+a 5^{*} \text { CPIC } t+ \\
& a 6 * Y R t-4+a 7 * F S t-7+ \\
& a 8^{*} \text { AFC }+a 9 * \text { SARS }+\varepsilon t
\end{aligned}
$$

In which OR $=$ Office Rent (Per square meter a month); OS = Office Stock (in meter. square); VR = Vacancy Rate (\%); FIREUR = FIRE Sector Unemployment Rate (\%); YR = Yield Rate (\%); FS = Forecast Supply (in meter. square); GDPG = GDP Growth; AFC = Dummy Variable (Asian Financial Crisis); SARS = Dummy Variable (Severe Acute Respiratory Syndrome).

It should be noted that two dummy variables are used. AFC represents the sudden shocking effect that the Asian Financial Crisis inflicted to Hong Kong, among many countries in the $3^{\text {rd }}$ quarter of 1997 . The SARS dummy variable, on the other hand, is used to reflect to the economic shock that accompanied the onslaught of the Severe Acute Respiratory Syndrome which started around the $2^{\text {nd }}$ quarter of 2003.

Regarding the factors that have negative correlations with office rent, it is reasonable to say that if the FIRE sector is adversely affected, the demand for labour in the sector is likely to fall, in which can be reflected by the FIRE sector unemployment rate, thus the demand for office space. This is the reason why a rise in FIRE sector unemployment induces a lower rental level. The situation of office stock is in line with the fundamental ideas in economics that the price of a good drops when its supply rises. The same can be applied to vacancy rate, as a higher vacancy rate indicates more vacant lots without any adjustments of office stock. In this case, it is easier to obtain office space at a lower cost. Then, a higher yield rate suggests that the office rental level is at a comparatively high level, given its price level. This is likely to discourage further demand for office space on the rental market, which then influences the rent negatively.

In addition, it is observed that office rent is lagging about 7 quarters behind forecast supply. As forecast supply is the figure reflecting the prediction of the market in a year, this suggests that the same figure about 9 months ago is significant in the determination of current office rent. Therefore, a higher forecast supply suggests a higher supply on the market, reducing the cost of renting office space in Central, even though the impact is not considered significant.

As expected, negative correlations between the SARS dummy variable and office rent is found. However, the AFC dummy variable demonstrates positive correlations with office rental levels in Hong Kong. Though counterintuitive in hindsight, it can be explained through the formation of office demand in Hong Kong. The Asian Financial Crisis, did not seem to affect the FIRE sector by that much. It can be shown in terms of the FIRE sector's contribution to Hong Kong's GDP, which the rate has been hovering around 20$27 \%$ over the years. The reason is that, Hong Kong, a city notorious for its high wage levels, became more competitive due to the declining labour cost. This made Hong Kong's service more attractive, which was the foundation of higher office space demand.

Dynamic Modeling:

Having set up the foundation of the study in the first stage, we enter the second stage, 
which is the adoption of the system dynamics model for forecasting the office rental adjustments. As seen in stage 1, five independent variables are selected in the model in explaining the movements of office rental levels in Hong Kong. However, it is reasonable to say that such five indicators are under the influence of some other variables, or perhaps among one another. As a result, five different regression models are constructed, determining the dynamics of the five independent variables in stage 1 (Figure 3). The reason behind such practice is that, spreadsheet analyses are static, regardless of the complexity of the macros. Those analyses do not take the changing dynamics of the market environment into account. A system dynamics model, on the other hand, does not only determine future rates under current market conditions, but changes that occur overtime from the interaction of different variables are considered as well (Tonelli, Cowley and Boyd, 2004). Also, pure regression analysis only allows a single relationship between dependent and independent variables at a time. Meanwhile, structural equation modeling (SEM) can estimate many interrelated equations at once, but it assumes the linearity of all relationships (Hair, 1998). It should be noted that, instead of putting arbitrary figures into the static model, the five equations illustrated below act as generators of the whole system, offering the dynamics for the determination of office rental levels. Similar to the practice in stage 1 , the selection of indepen-

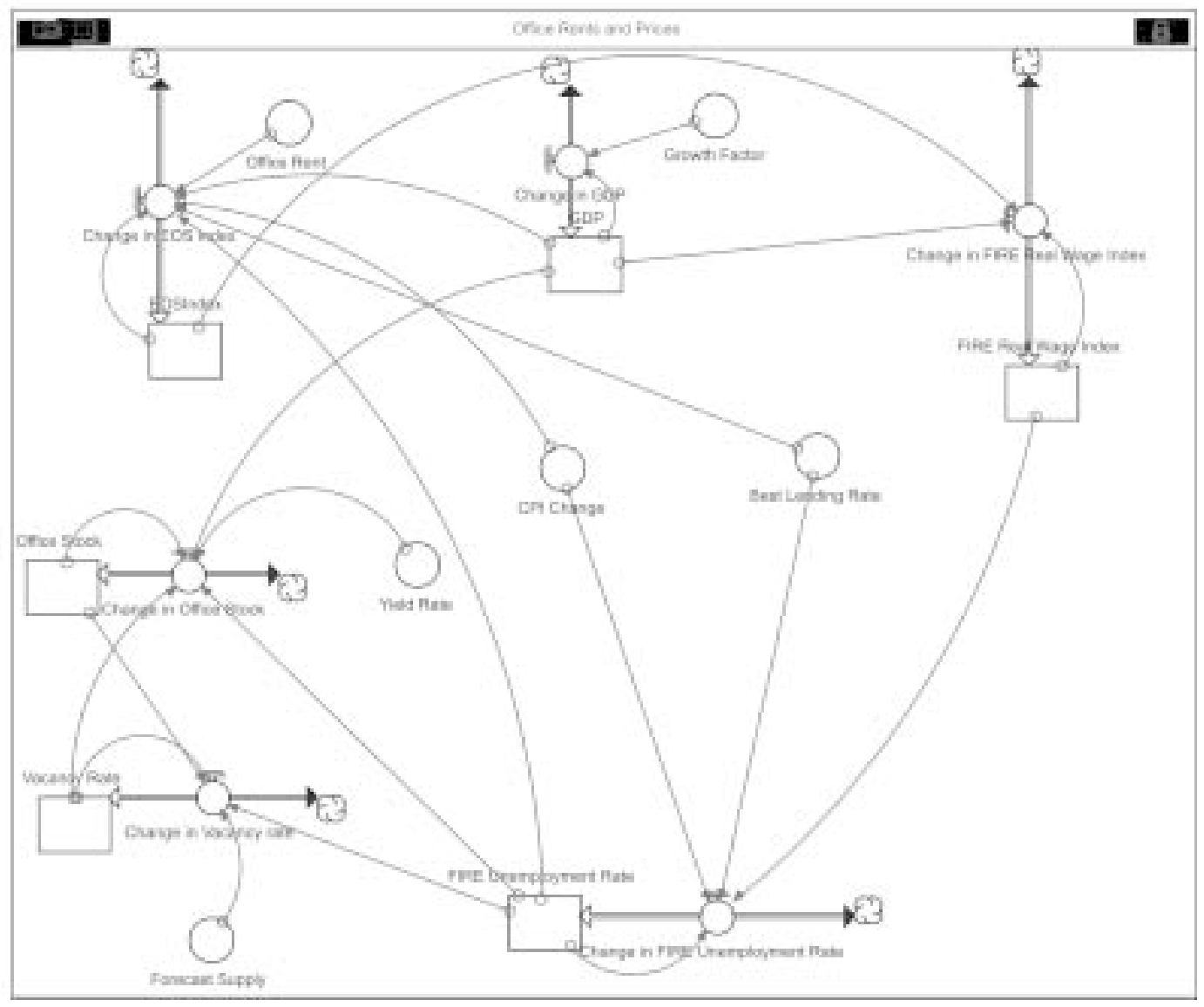

Figure 3. Conceptual map describing the interactions between the generators of the system dynamics model 
dent variables, thus their lead/lag relationships with the dependent variables, for the five equations presented below, are based on the results of the Cross-correlation tests.

$$
\begin{aligned}
& \text { FIREURt }=a 1+a 2^{*} C P I C t+a 3^{*} \\
& \text { BLRt }+a 4^{*} \text { FIRERWIt }-4+\varepsilon t \\
& \text { FIREWIt }=a 1+a 2 \text { EOSIt }- \\
& 3+a 3 * G D P t-1+\varepsilon t \\
& E O S I t=a 1+a 2 * B L R t+a 3^{*} G D P t+ \\
& a 4 * \text { CPICt }-2+a 5^{*} \text { FIREURt }-1+ \\
& a 6^{*} O R t+\varepsilon t \\
& O S t=a 1+a 2^{*} B L R t+a 3^{*} Y R t+ \\
& a 4^{*} \text { FIREURt }+a 5^{*} G D P t-1+\varepsilon t \\
& V R t=a 1+a 2 * \log (F S t-4)+ \\
& a 3 * \text { FIREURt }+a 4 * O S t+\varepsilon t
\end{aligned}
$$

where OS = Office Stock (in meter. square); VR = Vacancy Rate (\%); FIREUR = FIRE Sector Unemployment Rate (\%); FIREWI = FIRE Sector Real Wage Index; CPIC $=$ CPI Change $(\%)$; YR = Yield Rate (\%); FS = Forecast Sup- ply (in meter. square); BLR = Best Lending Rate (\%); OR = Office Rent (Per square meter a month); GDP = Gross Domestic Product (in HKD millions); EOSI = Export of Service Index.

\section{DESCRIPTIONS OF THE RESULTS FROM THE GENERATOR MODELS}

\section{On Office Stock}

The multiple regression model on office stock indicates that all of the variables are significant at $5 \%$ level. The GDP, with a lag of 1 quarter, poses a positive correlation with office stock. Office space demand is expected to rise in the upcoming future, thus a possible rise in rental income. As a result, the supply of office space is likely to go up as well.

Yield rate, on the other hand, is negatively correlated with office stock. But given the historical data of the Hong Kong office market, higher yield rates usually accompany relatively lower office prices on the sale market (Figure 4). In hindsight, those were times when the economy was in trouble, which was justified

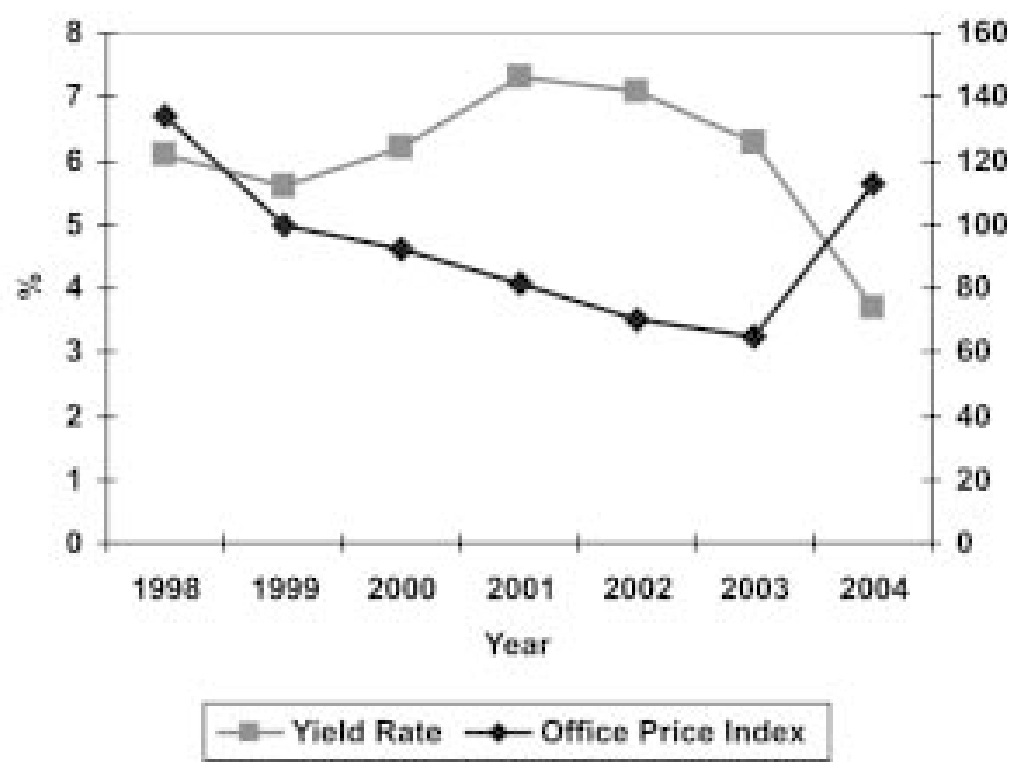

Figure 4. Yield Rates and Price Indices of Grade A Office, 1998-2004 (Source: Rating and Valuations Department) 
by the situations in Hong Kong after the Asian Financial Crisis. As a result, it is reasonable that a higher yield rate in Hong Kong tends to induce a lower level of office stock (Table 1).

\section{On Vacancy Rate}

The selected variables are both significant at $1 \%$ level and positively correlated with vacancy rate. A higher rate of FIRE sector unemployment reduces the demand for both labour and office space, thus enhancing the level of vacancy on the rental market. The situation with forecast supply is that the rental level of office space in Hong Kong has been declining since the $3^{\text {rd }}$ quarter of 1997. Any non-zero forecast supply, in addition to the falling demand reflected by the plummeting rental levels, could increase the amount of vacant lots on the market, thus resulting in a higher vacancy rate (Table 2 ).

\section{On FIRE Sector Unemployment Rate}

It is discerned that variables such as CPI change, best lending rate and the FIRE sector wage index 1 year ago (a lag of 4 quarters) are significant factors in explaining the dynamics of the FIRE sector unemployment rate. All of these factors are relating to the operating cost in the FIRE sector. The positive correlation between FIRE sector real wage index and the sector's unemployment is essentially under the same reasoning as the above two, only this time the labour cost is involved (Table 3 ).

Table 1. Regression results with Office Stock as the dependent variable

\begin{tabular}{lll}
\hline Variable & Coefficient (t-value) & p-value \\
\hline Constant & $733049.4(11.19296)$ & 0.0000 \\
Vacancy Rate t & $4771.173(2.178669)$ & 0.0337 \\
Yield Rate t & $-8317.713(-2.144128)$ & 0.0365 \\
FIRE Unemployment Rate t & $47094.23(6.287720)$ & 0.0000 \\
GDP t-1 & $1.697513(8.475125)$ & 0.0000 \\
\hline R-square & 0.954906 & \\
\hline
\end{tabular}

Table 2. Regression results with Vacancy Rate as the dependent variable

\begin{tabular}{lll}
\hline Variable & Coefficient (t-value) & p-value \\
\hline Constant & $-8.570517(-5.210202)$ & 0.0000 \\
Log(Forecast Supply t-4) & $1.273372(7.682222)$ & 0.0000 \\
FIRE Unemployment Rate t & $1.503076(10.90384)$ & 0.0000 \\
\hline R-square & 0.870976 & \\
\hline
\end{tabular}

Table 3. Regression results with FIRE Sector Unemployment Rate as the dependent variable

\begin{tabular}{lll}
\hline Variable & Coefficient (t-value) & p-value \\
\hline Constant & $2.773550(2.197935)$ & 0.0324 \\
CPI Change t & $-0.155881(-7.192738)$ & 0.0000 \\
Lending Rate t & $-0.271974(-4.834206)$ & 0.0000 \\
FIRE Real Wage Index t-4 & $0.025708(2.169522)$ & 0.0346 \\
\hline R-square & 0.810130 & \\
\hline
\end{tabular}




\section{On FIRE Sector Real Wage Index}

The EOS index (with a lag of 3 quarters) and GDP (with a lag of 1 quarter), are significant at $1 \%$ level in determining the FIRE sector real wage index. A higher level of GDP helps trigger more demand for goods and services, thus the labour required to provide such goods and services. This will push up the wage level of the FIRE sector. The negative correlation between EOS index and FIRE sector real wage index means a higher amount of service exported (in monetary terms), leads to a lower FIRE real wage index. At first glance, it seems illogical. But judging from the times series data, it can be told that the service sector has been gradually expanding, even when the economy was facing its downfall, especially after 1997. As a result, the wage level actually went down at the time, as more people were competing for jobs in this hot sector (Table 4).

\section{On Export of Service (EOS) Index}

Regarding the determination of the EOS index, the selected variables are significant in a statistical sense. It is not difficult to comprehend that a better economic condition, in terms of a higher GDP, usually correlates posi- tively with the amount of exports in service. A higher general price level (with a lag of 6 months), in this case, tends to induce a higher EOS index, as such rise in price level will provide a higher amount, in money terms, of the service exported. The FIRE sector unemployment rate (with a lag of 3 months) has a positive correlation with the EOS index. The reason is that a higher unemployment rate reduces the cost of hiring people into the sector.

On the other hand, higher office rents insinuate higher operating costs in providing services, which could lead to higher prices for the said services. This likely reduces the demand for Hong Kong's services. The cost concern is also applicable to the case of the negative correlations between best lending rate and EOS index (Table 5).

As the groundwork of the system dynamics model has already been completed, two scenarios are constructed, in order for us to see the adjustments of office rent under different economic conditions.

\section{Scenario 1:}

An expanding economy is currently the case with Hong Kong. Therefore, this scenario as-

Table 4. Regression results with FIRE Real Wage Index as the dependent variable

\begin{tabular}{lll}
\hline Variable & Coefficient (t-value) & p-value \\
\hline Constant & $19.17731(4.114555)$ & 0.0001 \\
EOS Index t-3 & $-0.247317(-4.897880)$ & 0.0000 \\
GDP t-1 & $0.000325(11.97683)$ & 0.0000 \\
\hline R-square & 0.824931 & \\
\hline
\end{tabular}

Table 5. Regression results with EOS Index as the dependent variable

\begin{tabular}{lll}
\hline Variable & Coefficient (t-value) & p-value \\
\hline Constant & $-47.83614(-4.296359)$ & 0.0001 \\
Lending Rate t & $-1.025979(-1.992584)$ & 0.0516 \\
GDP t & $0.000538(15.14791)$ & 0.0000 \\
CPI Change t-2 & $1.203079(4.376394)$ & 0.0001 \\
FIRE Unemployment Rare t-1 & $2.422015(1.810451)$ & 0.0760 \\
Office Rent t & $-0.038434(-3.757314)$ & 0.0004 \\
\hline R-square & 0.969034 & \\
\hline
\end{tabular}


sumes that the GDP would be growing constantly at $0.5 \%$ per quarter in the next 40 quarters (10 years) after the $4^{\text {th }}$ quarter of 2004 , for the purpose of simulations. This is the only controlled variable in the whole system, while other variables, such as yield rate, best lending rate, CPI change, and forecast supply, are assumed to be constant throughout the simulation period. The reason is that, under the current framework of the system, a change in one variable is enough for starting up the whole system, as what is being affected by the GDP (in this case) would in turn influence the other variables within the system. The process continues until the whole system functions. This can avoid the problem of selecting arbitrary, yet unrealistic, numbers for the study. The constants set for the aforementioned variables are extracted from the official data regarding such in the $4^{\text {th }}$ quarter of 2004 . This is also the case concerning the initial values of the dependent variable of all the multiple regression equations proposed in this study.

\section{Scenario 2:}

The conditions in scenario 2 are more or less the same as that in scenario 1 . The only difference is that the projected GDP growth is set at $1 \%$ /quarter, instead of $0.5 \%$ /quarter in scenario 1.

\section{TEST RESULTS}

By comparing both scenarios with one another (The results of the dynamics models, as a whole, are illustrated in Appendix 2), an interesting finding can be observed that lower office rental levels are being simulated in scenario 2 (Figure 5). While counterintuitive in hindsight, it can be explained by means of the interactions between demand and supply. Not only a higher level of demand for goods and services would be generated in economies with higher growth rates, the supply side would soon follow as well, due to the opportunities to obtain higher level of profits. However, there are two issues regarding such interactions.

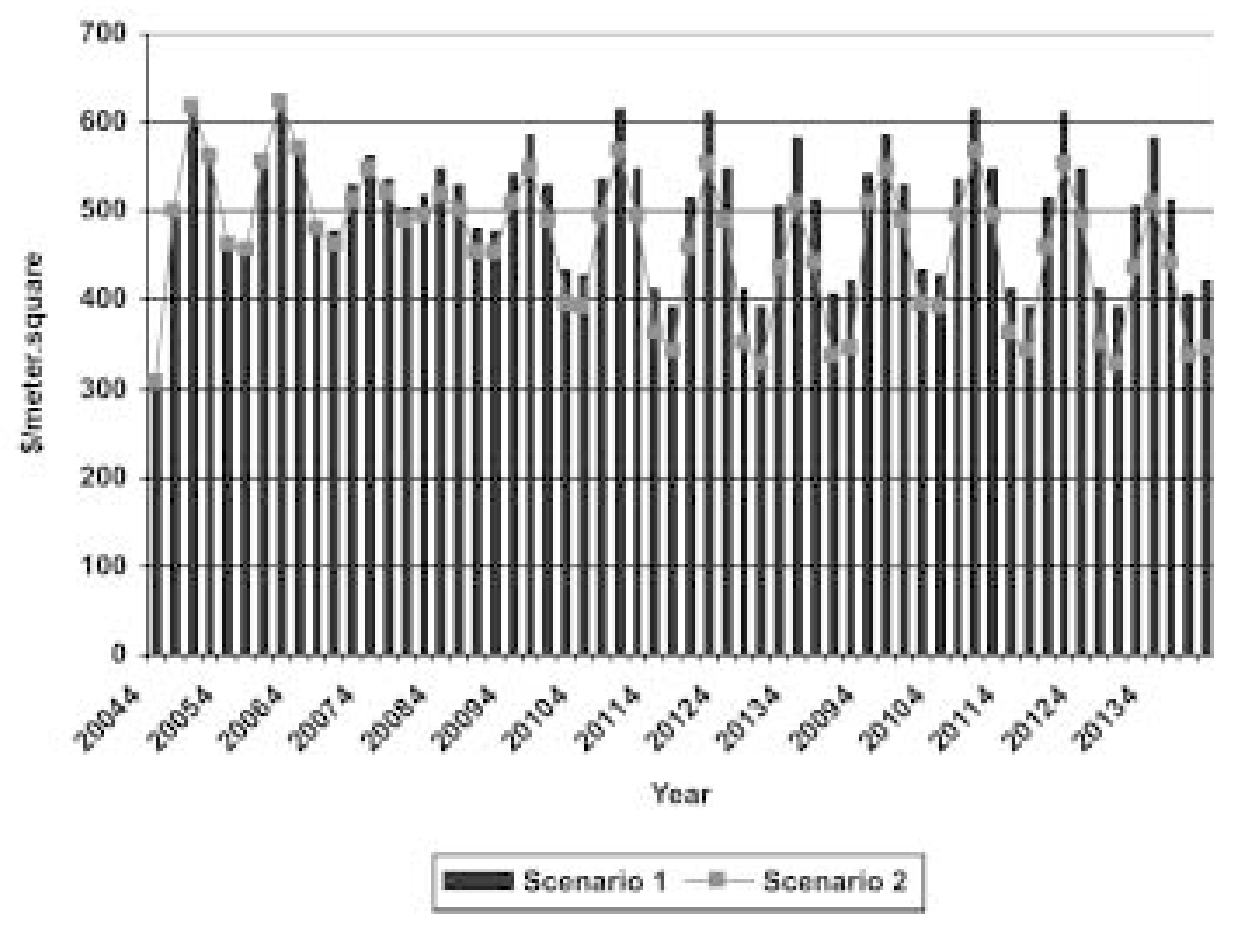

Figure 5. Simulated Office Rental Levels 
Firstly, the supply side appears to react even more optimistic towards positive economic trends, as illustrated in terms of a relatively higher positive adjustment of the supply of office stock in scenario 2 (Figure $6 \& 7$ ). The figures point out that by the time when the simulated rent is surging, a higher percentage change in office stock is simulated in scenario 2 than that in scenario 1 . Conversely, when the office rent is encountering a downturn, the supply side appears to react in a less pessimistic manner in scenario 2 , compared to scenario 1 as well.

Also, the asymmetrical occurrences of demand and supply changes play a crucial role as well, as longer time is required for the supply side to react to the sudden new waves of demand, which keeps adjusting over time. Given the critical issue of land scarcity in Hong Kong, new supply is likely generated from redevelopment or the existing vacant lots, or to a lesser extent, new constructions. During the adjustment period, the short-run rental levels are getting higher due to the new source of demand, given the relatively inept source of new supply. In the meantime, higher wage levels in the FIRE sector, and other sectors in general, are likely to occur (Figure 8), which induces higher operating cost for businesses in Hong Kong. Such positive ramifications on office rent would not last long, however, as businesses could start looking for cheaper office space elsewhere in order to reduce operating cost. This insinuates a fall in the demand for office space over time, which is in line with the general economics theories. Therefore, by the time when the new supply of office space is available, a fraction of the original demand has already been dissipated because of the higher short-term office rents. There would be a period of over-supply of office space and higher vacancy rates are likely to be the end result (Figure 9).

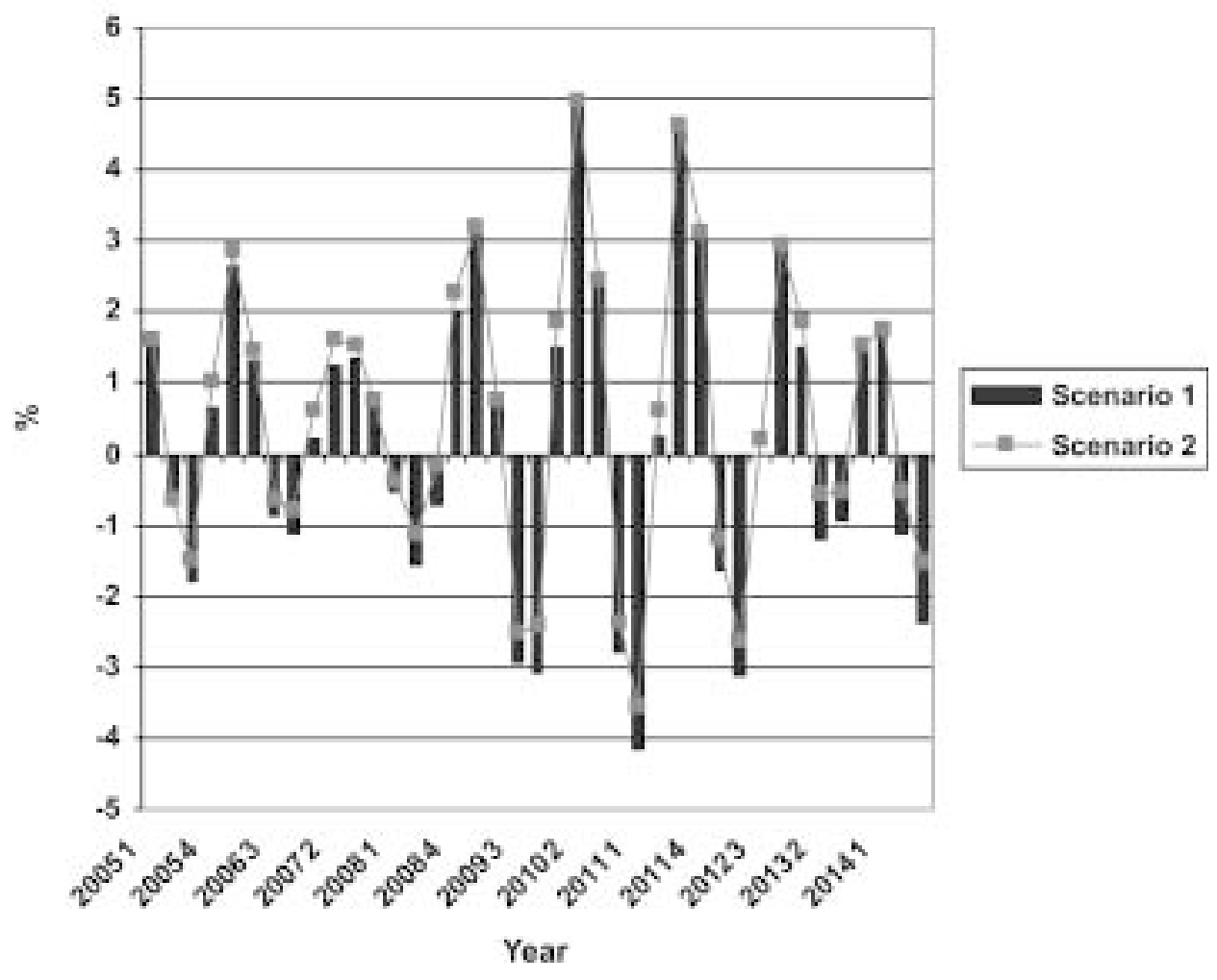

Figure 6. Percentage changes in Office Stock in the scenarios 


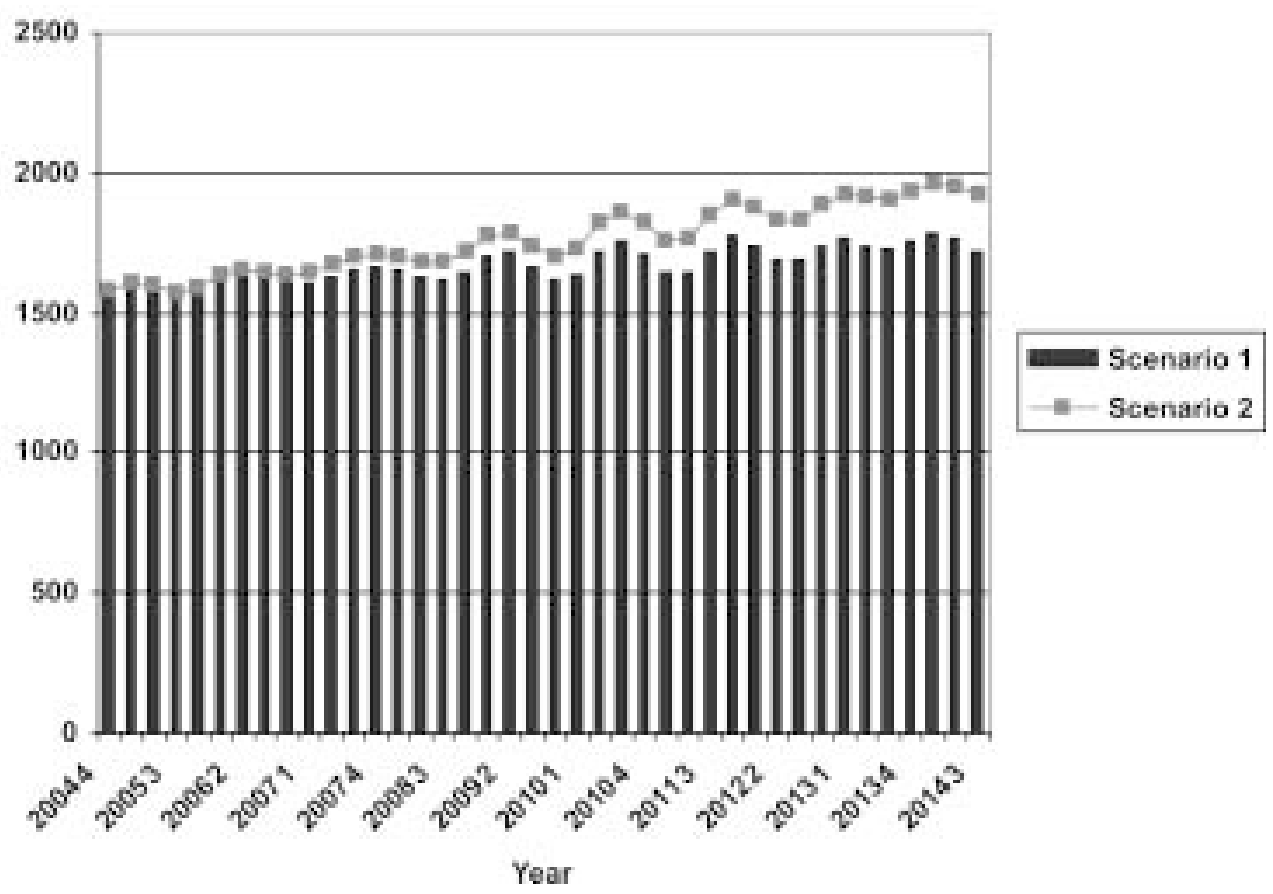

Figure 7. Simulated Office Stock (in '000 meters. square)

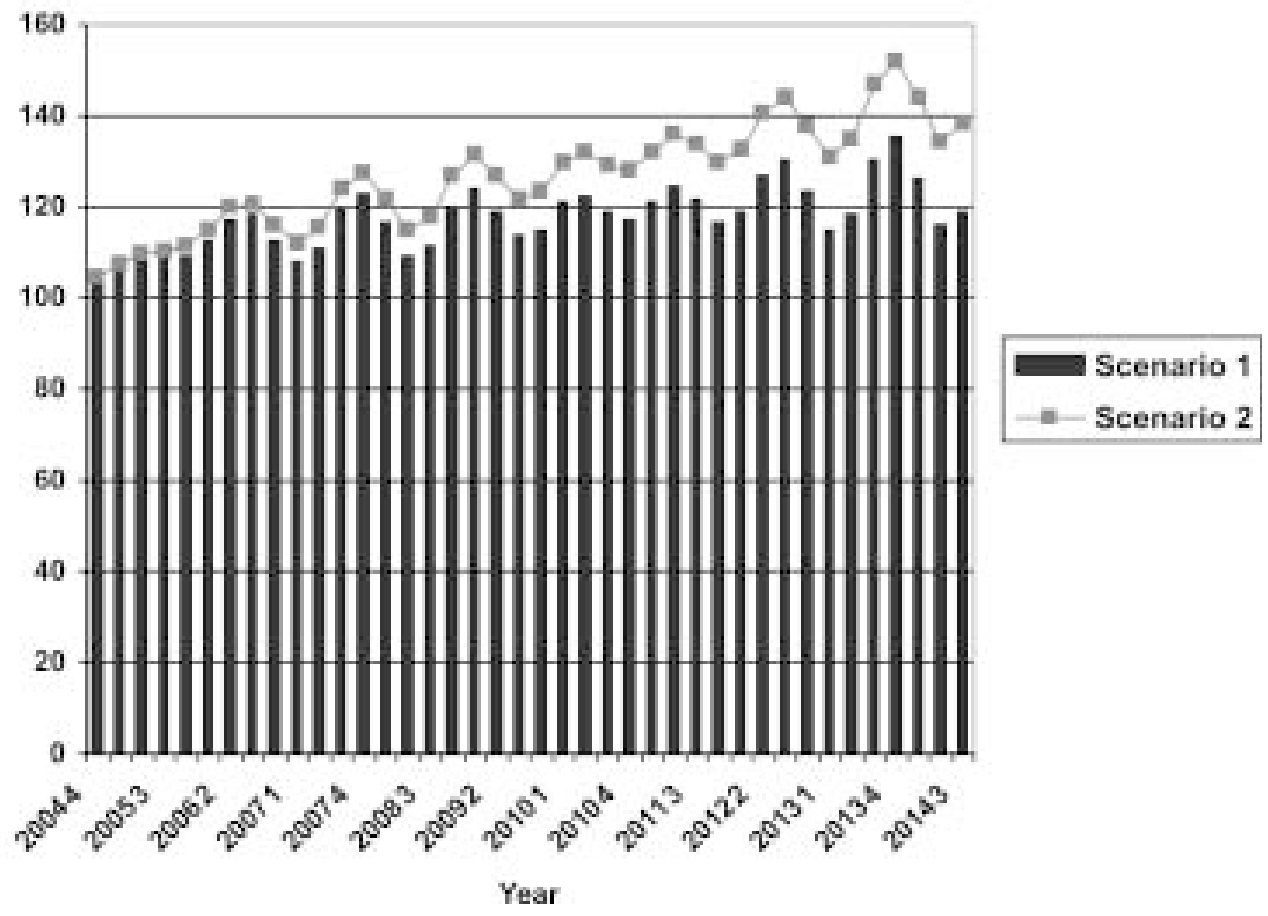

Figure 8. Simulated FIRE Sector Real Wage Rate 
In other words, the negative effect on office rents from the optimistic supply overwhelms the positive effects from the shorter-term positive demand adjustments, thus triggering further downward pressure on office rents. It can be observed in terms of the greater volatility in office rental adjustments and the lower rental levels in scenario 2 (Figure $5 \& 10$ ). This is in line with the conclusion made by Gallagher and Wood (1999) that the property market tends to over-react to economic trends, generating excess office construction and providing a negative impact on market performance. At worst, it could create extra uncer-

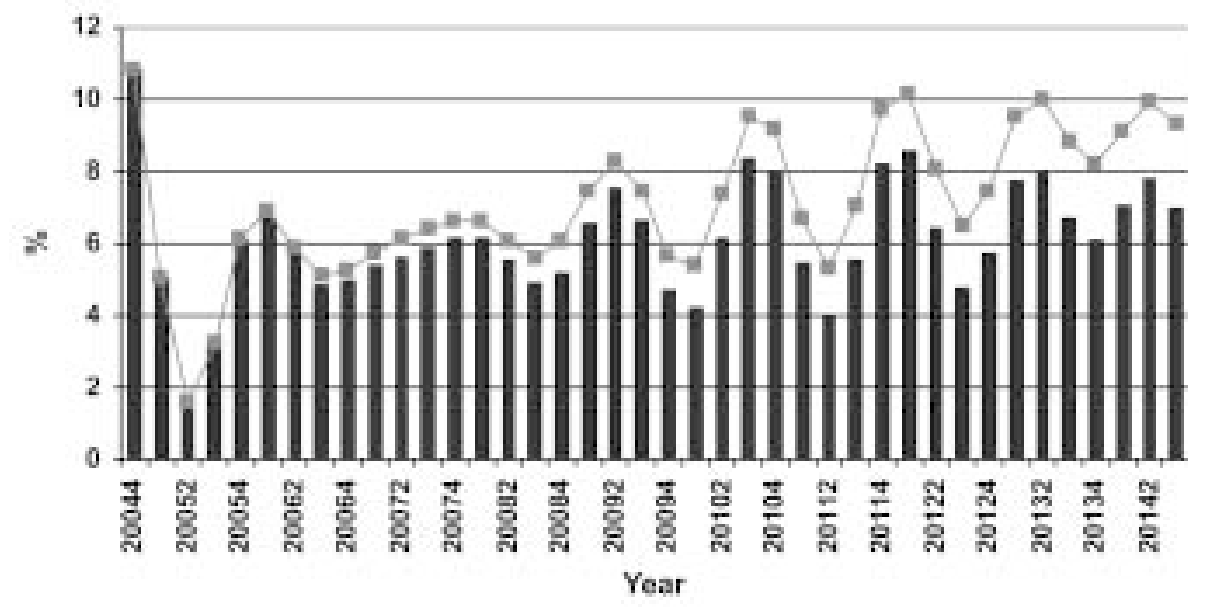

Ecenario $1-$ Scenario 2

Figure 9. The simulated vacancy rates of the scenarios

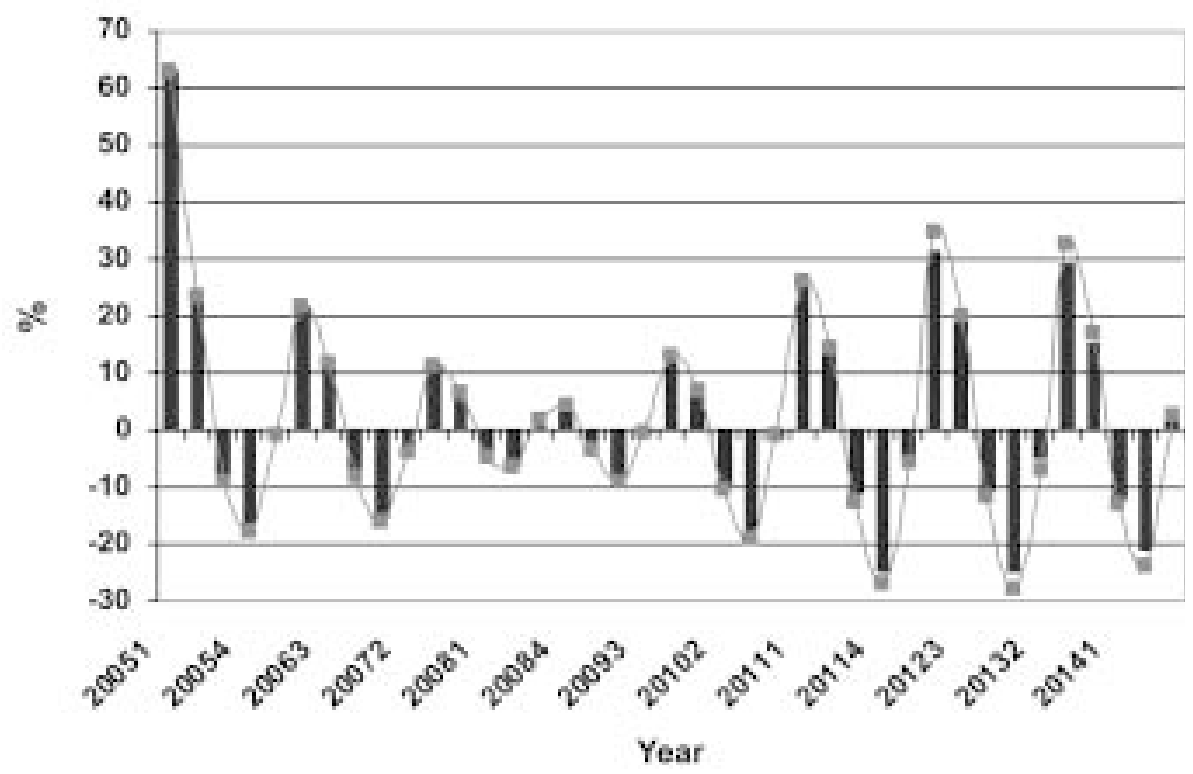

Scenario $1 \rightarrow-$ Scenario 2

Figure 10. Percentage changes of simulated rental values in the scenarios 
tainties in the business world that could end up adversely affecting Hong Kong's economy as a whole.

The results have some implications. From a market perspective, the higher volatility on office rents under better economic conditions insinuates the inefficiency of the property market. As stated by Gallagher and Wood (1999), the causes of these occurrences were quoted as being the long-term investment nature of real estate; development lags; space demand uncertainty; high adjustment (acquisition / disposal) costs; and the "unbridled enthusiasm" of developers. Expectations of better economic performance in the future likely induce higher demand for office space, thus triggering more supply of such either from existing vacant lots, new constructions or redevelopments. However, the problem is that it takes time for the supply side to react to the demand adjustments, especially when it involves new constructions or redevelopments. Meanwhile, the demand side constantly adjusts over time. Such asymmetrical occurrences of demand and supply could lead to erroneous predictions that could create an adverse effect on the performance of the market, which in hindsight is inevitable.

However, it is reasonable to say that the government's policies on land sales could exacerbate the existing problem of land market inefficiency. In Hong Kong, the government is the sole owner of land and the sale of land is determined by an application list system. The main feature of the arrangement is that in order to extract a piece of land from the application list, developers are required to offer a price for the land which is at least satisfactory from the government's perspective, before it could be put on sale in an open auction. The problem with this system is that if the price is not right from the government's point of view, the land on the application list would not be sold, though the demand for land for development exists. In other words, such arrangement could further increase the cost for development and/ or postpone the supply of space. Under market mechanisms, the increasing demand for office space would be reflected in an upward movement of office rents, which would then induce a negative impact on the demand for office space. By the time when new supply of office spaces is available, the originally anticipated demand change has either been absorbed by the existing office stock back then, or driven away by the higher rental levels. This could lead to even higher discrepancies between demand and supply, thus resulting in a more fluctuating office leasing market. This could reduce the attractiveness to set up businesses in Hong Kong, due to its uncertainty. We suggest that such arrangement should be eliminated, in order to reduce the transaction cost incurred in developments and to restrain the volatilities on the office space market.

Aside from the revision of the existing land sales arrangements, there is something that the government could possibly do in order to keep the office leasing market from being too volatile. While demand side uncertainties are more or less out of the control of the government, the government's land use policies appear to play a role in affecting supply-side elements such as adjustment cost and development lags. There are two procedures that need to be completed before any redevelopment projects take place. Firstly, developers need to obtain the approval of government agencies in order to modify the usage of an area. Secondly, a premium payment is required before the commencement of any redevelopment projects. It can be said that these two measures, coupled with the high land price policy adopted by the government, are significant in determining the adjustment cost and the development lags of office space supply. The government could relax the first two institutional measures, such as speeding up the approval process for the applications for changing land use and probably re-arranging the payment of premiums after the redevelopment process. This could help reduce the adjustment cost and development lags, thus decreasing the volatility (or the price risk) of the office user (leasing) market. 


\section{CONCLUSION}

Two scenario studies are conducted in an attempt to explore the dynamics of office rental levels in Hong Kong, under different economic conditions. The paper introduces a generator approach, with the integration of system dynamics and econometric modeling as the basis. This eliminates the problems associated with static regression models used in previous studies. Further, by incorporating econometric models, irrelevant factors would be screened out. This is a more rounded approach that is able to obtain more realistic results, which are the basis of better decisions.

The results suggest that comparatively lower office rental levels and a more volatile office leasing market are likely to exist under better economic conditions (as in scenario 2), due to the supply side's tendency of being relatively optimistic to market trends. This probably generates excess office supply to the point where its negative impact on office rents dominates the positive effect that comes from the increasing demand. It is also believed that government policies on land sales play a role in postponing the reaction time of the supply side. Further, it is also expected that the land use policies exert some influence in determining the development lags and adjustment cost of development projects. Both institutional arrangements, which incur higher transaction cost in supplying new office space, in a sense exacerbate the discrepancies between demand and supply over time, thus creating a relatively uncertain office market.

In order to reduce the high volatilities on the office leasing market, the government should relax its land use policies, such as the modification of the existing decrees on land use and premium arrangements. Also, the existing land sales policies, in particular regarding the application list system, should be revised or at best eliminated, to bring more flexibility to the supply-side. This could reduce the time needed and the transaction cost involved for the supply side to adjust to the everchanging demand and diminish the volatility on the office rental market.

\section{REFERENCES}

Armstrong, R.B. (1979) The Office Industry: Patterns of Growth and Location, The MIT Press, Cambridge.

Born, W.L. \& Pyhrr, S.A. (1994) Real estate valuation: the effect of market and property cycles. Journal of Real Estate Research, 9(4), p. 455486.

Canter, T., Gordon, J. \& Mosbaugh, P. (1996) Integrating regional economic indicators with the real estate cycle. Journal of Real Estate Research, 12(3), p. 469-485.

Chesterton Petty (2004) Hong Kong Property Market Annual Report 2003-2004.

Clapp, J.M. (1993) Dynamics of Office Markets: Empirical Findings and Research Issues, The Urban Institute Press, Washington D.C.

Cowley, M. (2003) Property Market Cycle, Masters Dissertation, Queensland University of Technology.

D’Arcy, E., McGough, T. and Tsolacos, S. (1997) National Economic Trends, Market Size and City Growth Effects on European Office Rents. Journal of Property Research, 14(4), p. 297-308.

D’Arcy, E., McGough, T. and Tsolacos, S. (1999) An Econometric Analysis and Forecasts of the Office Rental Cycle in the Dublin Area. Journal of Property Research, 16(4), p. 309-321.

DiPasquale, D. \& Wheaton, W. (1994) Housing Market Dynamics and the Future of Housing Prices. Journal of Urban Economics, 35, p. 127.

Forrester, J. (1969) Urban Dynamics, Productivity Press, Portland, Oregon.

Forrester, J. (1992) Policies, decisions and information sources for modeling. European Journal of Operational Research, 59(1), p. 42-63.

Gardiner, C. and Henneberry, J. (1988) The Development of Simple Regional Office Rent Prediction Model. Journal of Property Valuation, 7(1), p. 36-52.

Giussani, B., Hsia, M. and Tsolacos, S. (1993) A Comparative Analysis of the Major Determinants of Office Rental Values in Europe. Journal of Property Valuation and Investment, 11(2), p. 157-173. 
Grissom, T. \& DeLisle, J.R. (1999) A multiple index analysis of real estate cycles and structural change. Journal of Real Estate Research, 18(1), p. 97-129.

Hair, J.F. (1998) Multivariate Data Analysis, Prentice Hall, Upper Saddle River, N.J.

Hekman, J.S. (1985) Rental Price Adjustments and Investments in the Office Market. AREUEA Journal, 13(1), p. 32-

Hendershott, P. (1996) Rental adjustment and valuation in overbuilt markets: evidence from the Sydney office market. Journal of Urban Economics, 39(1), p. 51-67.

Hendershott, P., Lizieri, C. \& Matysiak, G. (1999) The workings of the London office market. Real Estate Economics, 30(2), p. 165-183.

Howland, M. \& Wessel, D.S. (1994) Projecting Suburban Office Space Demand: Alternative Estimates of Employment in Offices. Journal of Real Estate Research, 9(3), p. 369-389.

$\mathrm{Hu}$, Y.C. \& Shen, Q.P. (2000) STAR: a system dynamics model for urban housing development in Hong Kong. Property Management, 4(1), p. $39-43$.

Jones Lang LaSelle (2003) A Mature Office Market - A Key Ingredient in Hong Kong's Future Success. October 2003.

Jayantha, W.M. and Ganesan, S. (2002) Econometric analysis of office space market's response to service sector growth in Hong Kong. Journal of Financial Management of Property and Construction, 7(3), p. 175-195.

Kummerow, M. (1997) Commercial Property Valuations with Cyclical Forecasts. The Valuer \& Land Economist, 34(5), p. 424-428.

Kummerow, M. (1999) A Systems Dynamics Model of Cyclical Office Oversupply. Journal of Real Estate Research, 18(1), p. 233-255

Liow, K.H. (2000) The Dynamics of the Singapore Commercial Property Market. Journal of Property Research, 17(4), p. 279-291.

Lyneis, J. (2000) System Dynamics for Market Forecasting and Structural Analysis. System Dynamics Review, 16(1), p. 3-24.

McDonald, J.F. (2002) A survey of econometric models for office markets. Journal of Real Estate Literature, 10(2), p. 223-242.

McGough, T. \& Tsolacos, S. (1995) Forecasting commercial rental values using ARIMA models. Journal of Property Valuation and Investment, 13(5), p. 6-22.
Pollakowski, H., Wachter, S. \& Lynford, L. (1992) Did Office Market Size Matter in the 1980s? A Time-Series Cross Sectional Analysis of Metropolitan Area Office Markets. AREUEA Journal, 20(2), p. 303-324.

Rosen, K.T. (1984) Toward a Model of the Office Building Sector. AREUEA Journal, 12(3), p. 261-269.

Sterman, J.D. (1988) Modeling the Formation of Expectations: The History of Energy Demand Forecasts. International Journal of Forecasting, 4, p. 243-259.

Sterman, J.D. (2000) Business Dynamics: Systems Thinking and Modeling for a Complex World, Irwin/McGraw-Hill, Chicago, IL.

Tonelli, M., Cowley, M., and Boyd, T. (2004) Forecasting Office Building Rental Growth Using a Dynamic Approach. Pacific Rim Property Research Journal, 10(3), p. 283-304.

Tsolacos, S., Keogh, G., and McGough (1998) Modelling Use, Investment and Development in the British Office Market. Environment and Planning A, 30(8), p. 1409-1427.

Vennix, J. (1996) Group Model Building, Wiley \& Sons, England.

Wheaton, W.C. (1987) The Cyclic Behaviour of the National office market. AREUEA Journal, 15(4), p. 281-299.

Wheaton, W.C., Torto, R.G. (1988) Vacancy rates and the future of office rents. AREUEA Journal, 16(4), p. 430-436.

Wheaton, W.C., Torto, R.G. \& Evans, P. (1997) The cyclic behaviour of the London office market. Journal of Real Estate Finance and Economics, 15(1), p. 77-92.

\section{Other Sources:}

Rating \& Valuation Department http:// www.info.gov.hk/rvd

Census \& Statistics Department Http:// www.info.gov.hk/censtatd

HSBC http://www.hsbc.com.hk

Hong Kong Property Review (various issues), Ratings and Valuation Department, The Hong Kong Government 


\section{SANTRAUKA}

\section{HONKONGO BIURU NUOMOS RINKOS DINAMIKA}

\section{Eddie Chi Man HUI, Ka Hung YU}

Biurų nuomos prognozès yra tarp dažniausiai nagrinėjamų nekilnojamo turto tyrimų temų. Tačiau dẻl geriausio prognozavimo metodo vis dar vyksta karšti debatai. Šiame straipsnyje pateikiamas generatoriaus metodas, pagrịstas sistemos dinamika ir ekonometriniu modeliavimu. Išvados rodo, kad Honkonge biurų nuomos vertės esti labiau kintamos ir neapibrěžtos, kai ekonominès sąlygos yra geresnès. Taip yra greičiausiai dèl to, kad turto rinkoje veikiantys tiekejjai pernelyg optimistiškai žiūri į ekonomines tendencijas, kad vèluoja plètra ir reguliavimo sąnaudos, veikiamos dabartinès krašto politikos Honkonge. Tai yra pagrindinès su šiuo reiškiniu susijusios temos. Norẻdama sumažinti biurų nuomos rinkos neapibrèžtumą, vyriausybẻ turètų supaprastinti patvirtinimo procedūras, susijusias su kintančia žemès paskirtimi, bei su tuo susijusius įmokų mokejimo pertvarkymus. Be to, reikètų pakoreguoti esamą prekybos žeme politiką, ypač sklypų sąrašų sistemą. Šios priemonès galètų sumažinti laiką ir patiriamas transakcijų išlaidas, taip paskatindamos greitesnę reakciją i̊ paklausos pokyčius, laikui bėgant. 


\section{APPENDIX 1}

The lead/lag relationships between various variables and the office rental level used for the first model (Model 1) are based on the results obtained by the Granger Causality tests. The results of the tests are illustrated in Table A below.

Table A. Results of the lead/lag relationships between Office Rent and other variables through Granger Causality Tests (** represents the optimal lead/lag relationships used in Model 1)

\begin{tabular}{|c|c|c|c|}
\hline Null Hypothesis & $\operatorname{Lag}(\mathrm{s})$ & F-Statistics & Probability \\
\hline \multirow[t]{4}{*}{ 1a. Forecast Supply does not Granger Cause Office Rent } & 1 & 9.57155 & $0.00308 * *$ \\
\hline & 2 & 2.10449 & 0.13198 \\
\hline & 3 & 1.24438 & 0.30357 \\
\hline & 4 & 0.91748 & 0.46170 \\
\hline \multirow[t]{4}{*}{ 1b. Office Rent does not Granger Cause Forecast Supply } & 1 & 0.70388 & 0.40505 \\
\hline & 2 & 1.19993 & 0.30926 \\
\hline & 3 & 1.20472 & 0.31768 \\
\hline & 4 & 1.36556 & 0.26020 \\
\hline \multirow[t]{4}{*}{ 2a. CPI Change does not Granger Cause Office Rent } & 1 & 1.29882 & 0.25928 \\
\hline & 2 & 1.09583 & 0.34171 \\
\hline & 3 & 0.95798 & 0.41990 \\
\hline & 4 & 3.07823 & 0.02481 \\
\hline \multirow[t]{4}{*}{ 2b. Office Rent does not Granger Cause CPI Change } & 1 & 0.83899 & 0.36361 \\
\hline & 2 & 6.56060 & $0.00285^{* *}$ \\
\hline & 3 & 5.25112 & 0.00315 \\
\hline & 4 & 4.23786 & 0.00520 \\
\hline \multirow{4}{*}{$\begin{array}{l}\text { 3a. FIRE Unemployment Rate does not Granger Cause Office } \\
\text { Rent }\end{array}$} & 1 & 11.0413 & $0.00157 * *$ \\
\hline & 2 & 4.92852 & 0.01089 \\
\hline & 3 & 2.46927 & 0.07268 \\
\hline & 4 & 2.39337 & 0.06380 \\
\hline \multirow{4}{*}{$\begin{array}{l}\text { 3b. Office Rent does not Granger Cause FIRE Unemployment } \\
\text { Rate }\end{array}$} & 1 & 0.95971 & 0.33147 \\
\hline & 2 & 2.18115 & 0.12294 \\
\hline & 3 & 1.66722 & 0.18594 \\
\hline & 4 & 2.29915 & 0.07269 \\
\hline \multirow[t]{4}{*}{ 4a. Office Stock does not Granger Cause Office Rent } & 1 & 1.61947 & 0.20842 \\
\hline & 2 & 2.07886 & $0.13515^{* *}$ \\
\hline & 3 & 1.09261 & 0.36091 \\
\hline & 4 & 1.44984 & 0.23257 \\
\hline \multirow[t]{4}{*}{ 4b. Office Rent does not Granger Cause Office Stock } & 1 & 0.14749 & 0.70240 \\
\hline & 2 & 0.06416 & 0.93793 \\
\hline & 3 & 0.41073 & 0.74599 \\
\hline & 4 & 0.22745 & 0.92167 \\
\hline \multirow[t]{5}{*}{ 5a. Yield Rate does not Granger Cause Office Rent } & 1 & 10.4815 & $0.00203 * *$ \\
\hline & 2 & 1.34649 & 0.26890 \\
\hline & 3 & 4.18299 & 0.01018 \\
\hline & 4 & 3.27066 & 0.01906 \\
\hline & & & (conti \\
\hline
\end{tabular}




\begin{tabular}{llll}
\hline Null Hypothesis & Lag(s) & F-Statistics & Probability \\
\hline (continued) & & & \\
5b. Office Rent does not Granger Cause Yield Rate & 1 & 3.39319 & 0.07076 \\
& 2 & 1.22481 & 0.30199 \\
& 3 & 2.11501 & 0.11005 \\
& 4 & 0.89220 & 0.47609 \\
6a. Vacancy Rate does not Granger Cause Office Rent & 1 & 12.4780 & $0.00083^{* *}$ \\
& 2 & 4.15943 & 0.02099 \\
& 3 & 2.04347 & 0.11968 \\
6b. Office Rent does not Granger Cause Vacancy Rate & 4 & 1.77040 & 0.15066 \\
& 1 & 0.22151 & 0.63972 \\
& 2 & 0.95297 & 0.39210 \\
& 3 & 0.89932 & 0.44816 \\
\hline
\end{tabular}

The resulting equation for Model 1 is depicted as follows:

$$
\begin{aligned}
& \text { ORt }=a 1+a 2 * O S t-2+a 3^{*} V R t-1+ \\
& a 4^{*} \text { FIREURt }-1+a 5^{*} G D P G t-2+ \\
& a 6^{*} Y R t-1+a 7^{*} F S t-1+a 8^{*} A F C+ \\
& a{ }^{*} \text { SARS }+\varepsilon t
\end{aligned}
$$

The basis of the lead/lag relationships between office rent and other variables in the construction of Model 2 is the results obtained from the cross-correlations tests among the aforementioned variables. The results are presented in Table B below.

Based on the results, the regression equation for Model 2 is as follows,

$$
\begin{aligned}
& \text { ORt }=a 1+a 2 * O S t+a 3^{*} V R t-4+ \\
& a 4^{*} \text { FIREUR }-1+a 5^{*} C P I C t+ \\
& a 6^{*} Y R t-4+a 7 * F S t-7+ \\
& a 8^{*} A F C+a 9^{*} \text { SARS }+\varepsilon t
\end{aligned}
$$

Consequently, the results from both models are presented in Table $\mathrm{C}$.

It should be noted that the vacancy rate with a lag of 1 year (4 quarters), instead of 3 quarters, is used in Model 2. It is because of the problems encountered when putting the vacancy rate (with 3 quarters of lag) into the Model. The result implies that the variable is statistically insignificant. It somehow can be explained by the fact that the vacancy rate (provided on a yearly basis) is assumed to be constant over the entire calendar year, due to data limitations.

Table B. Cross-Correlation Tests results obtained for the construction of Model 2 (** represents the optimal lead/lag relationships used in Model 2)

\begin{tabular}{llll}
\hline Variables & Lag $(\mathrm{s})$ & Cross-Correlations & Std. Error \\
\hline Office Rent $\rightarrow$ FIRE Unemployment Rate & -7 & -.541 & .137 \\
& -6 & -.613 & .136 \\
& -5 & -.677 & .135 \\
& -4 & -.741 & .134 \\
& -3 & -.795 & .132 \\
& -2 & -.833 & .131 \\
& -1 & $-.839 * *$ & .130 \\
(continued)
\end{tabular}




\begin{tabular}{|c|c|c|c|}
\hline Variables & $\operatorname{Lag}(s)$ & Cross-Correlations & Std. Error \\
\hline \multicolumn{4}{|l|}{ (continued) } \\
\hline \multirow[t]{8}{*}{ Office Rent $\rightarrow$ Office Stock } & -7 & -.558 & .137 \\
\hline & -6 & -.576 & .136 \\
\hline & -5 & -.595 & .135 \\
\hline & -4 & -.614 & .134 \\
\hline & -3 & -.639 & .132 \\
\hline & -2 & -.664 & .131 \\
\hline & -1 & -.681 & .130 \\
\hline & 0 & $-.705 * *$ & .129 \\
\hline \multirow[t]{8}{*}{ Office Rent $\rightarrow$ CPI Change } & -7 & .661 & .137 \\
\hline & -6 & .653 & .136 \\
\hline & -5 & .664 & .135 \\
\hline & -4 & .674 & .134 \\
\hline & -3 & .691 & .132 \\
\hline & -2 & .710 & .131 \\
\hline & -1 & .712 & .130 \\
\hline & 0 & $.713^{* *}$ & .129 \\
\hline \multirow[t]{8}{*}{ Office Rent $\rightarrow$ Vacancy Rate } & -7 & -.459 & .146 \\
\hline & -6 & -.558 & .144 \\
\hline & -5 & -.650 & .143 \\
\hline & -4 & $-.729 * *$ & .141 \\
\hline & -3 & -.744 & .140 \\
\hline & -2 & -.734 & .139 \\
\hline & -1 & -.703 & .137 \\
\hline & 0 & -.654 & .136 \\
\hline \multirow[t]{8}{*}{ Office Rent $\rightarrow$ Yield Rate } & -7 & -.314 & .137 \\
\hline & -6 & -.383 & .136 \\
\hline & -5 & -.410 & .135 \\
\hline & -4 & $-.425 * *$ & .134 \\
\hline & -3 & -.383 & .132 \\
\hline & -2 & -.304 & .131 \\
\hline & -1 & -.200 & .130 \\
\hline & 0 & -.073 & .129 \\
\hline \multirow[t]{8}{*}{ Office Rent $\rightarrow$ Forecast Supply } & -7 & $-.492 * *$ & .146 \\
\hline & -6 & -.480 & .144 \\
\hline & -5 & -.455 & .143 \\
\hline & -4 & -.385 & .141 \\
\hline & -3 & -.303 & .140 \\
\hline & -2 & -.211 & .139 \\
\hline & -1 & -.103 & .137 \\
\hline & 0 & -.033 & .136 \\
\hline
\end{tabular}

It is found out that the variables selected for the determination of office rent in Model 2 are statistically significant, while such cannot be said about Model 1. In Model 1, the statis- tically significant factors include only the FIRE sector unemployment rate, yield rate and GDP growth. Interestingly, the results suggest that a higher GDP growth is likely to induce a lower 
Table C. Regression results of Models $1 \& 2$

\begin{tabular}{|c|c|c|c|c|c|}
\hline \multicolumn{3}{|l|}{ Model 1} & \multicolumn{3}{|l|}{ Model 2} \\
\hline Variable & $\begin{array}{l}\text { Coefficient } \\
\text { (T-value) }\end{array}$ & $\mathrm{P}$-value & Variable & $\begin{array}{l}\text { Coefficient } \\
\text { (T-value) }\end{array}$ & $\mathrm{P}$-value \\
\hline Constant & $\begin{array}{l}827.0872 \\
(3.485855)\end{array}$ & 0.0010 & Constant & $\begin{array}{l}1301.998 \\
(7.831317)\end{array}$ & 0.0000 \\
\hline $\begin{array}{l}\text { FIRE Sector } \\
\text { Unemployment Rate } t-1\end{array}$ & $\begin{array}{l}-85.28911 \\
(-3.962388)\end{array}$ & 0.0002 & $\begin{array}{l}\text { FIRE Sector } \\
\text { Unemployment Rate } \mathrm{t}-1\end{array}$ & $\begin{array}{l}-21.25092 \\
(-1.761646)\end{array}$ & 0.0851 \\
\hline Office Stock t-2 & $\begin{array}{l}8.91 \mathrm{E}-05 \\
(0.478886)\end{array}$ & 0.6341 & Office Stock t & $\begin{array}{l}-0.000263 \\
(-2.117878)\end{array}$ & 0.0399 \\
\hline Vacancy Rate $\mathrm{t}-1$ & $\begin{array}{l}-7.421234 \\
(-1.668500)\end{array}$ & 0.1016 & Vacancy Rate $\mathrm{t}-4$ & $\begin{array}{l}-8.140640 \\
(-2.854361)\end{array}$ & 0.0066 \\
\hline Yield Rate $\mathrm{t}-1$ & $\begin{array}{l}-27.60351 \\
(-3.305587)\end{array}$ & 0.0018 & Yield Rate $\mathrm{t}-4$ & $\begin{array}{l}-53.47544 \\
(-8.943814)\end{array}$ & 0.0000 \\
\hline Forecast Supply $\mathrm{t}-1$ & $\begin{array}{l}0.000261 \\
(1.016266)\end{array}$ & 0.3145 & Forecast Supply t-7 & $\begin{array}{l}-0.000382 \\
(-2.121424)\end{array}$ & 0.0396 \\
\hline GDP Growth $\mathrm{t}-2$ & $\begin{array}{l}-14.35929 \\
(-2.364321)\end{array}$ & 0.0221 & CPI Change t & $\begin{array}{l}5.936835 \\
(2.866794)\end{array}$ & 0.0063 \\
\hline $\mathrm{AFC}$ & $\begin{array}{l}34.94022 \\
(0.477052)\end{array}$ & 0.6354 & $\mathrm{AFC}$ & $\begin{array}{l}73.39152 \\
(1.759889)\end{array}$ & 0.0854 \\
\hline SARS & $\begin{array}{l}17.46948 \\
(0.236755)\end{array}$ & 0.8138 & SARS & $\begin{array}{l}-27.44340 \\
(-0.644401)\end{array}$ & 0.5227 \\
\hline R-Square & 0.827384 & & R-Square & 0.944897 & \\
\hline
\end{tabular}

office rental level, which seems counterintuitive in nature.

On the other hand, in Model 2, with the exception of CPI change, the remaining variables have negative correlations with the office rental level. The positive correlation between CPI change and office rent suggests that as the general price level increases, the office rental level is going to follow. An increase in general price level indicates a higher level of demand for goods and services in general. As mentioned before, due to the undeniable role of the service sector in deciding the demand for office space, higher service demand likely induces higher office demand, thus pushing up the office rental level.
Either one of the two models would be selected as the basis of the dynamic model presented in the second stage. The more appropriate model is chosen, based on its accuracy in forecasting the office rental adjustments. One way of doing such is to compare the results of the two models with the historical data on office rent in Hong Kong. A Pearson correlation test is conducted and the results are presented in Table D.

The results suggest that Model 2, with variables chosen on the basis of cross-correlation testing, fits the historical office rental data in a more accurate manner. As a result, Model 2 is selected as the static modeling stage of this study.

Table D. Pearson Correlation test results

\begin{tabular}{ll}
\hline & Pearson Correlation with historical office rental data (sig.) \\
\hline Model 1 & $0.914^{* *}(.000)$ \\
Model 2 & $0.972 * *(.000)$ \\
\hline
\end{tabular}




\section{APPENDIX 2}

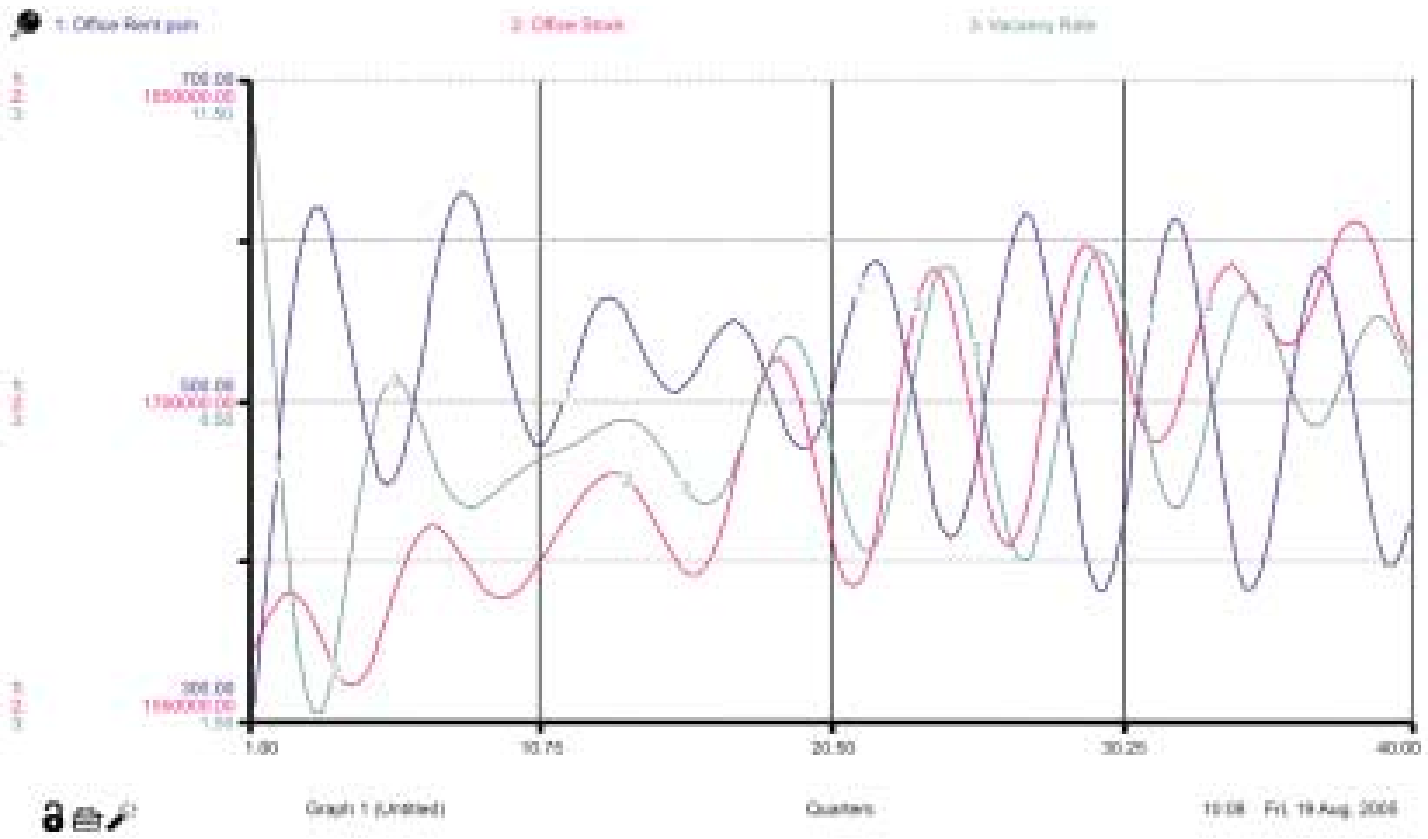

Figure A1. Results of Scenario 1

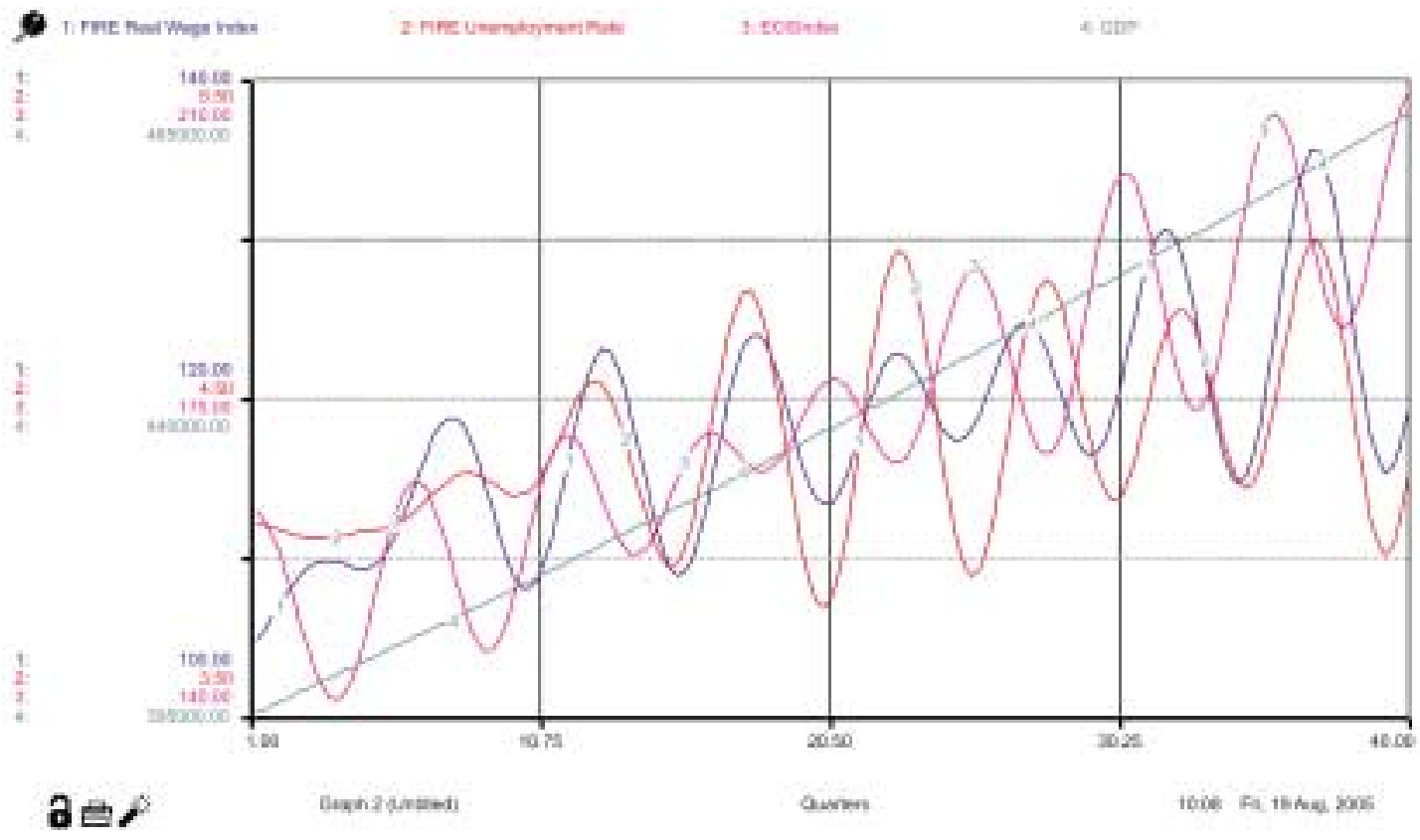

Figure A2. Results of scenario 1 (cont'd) 


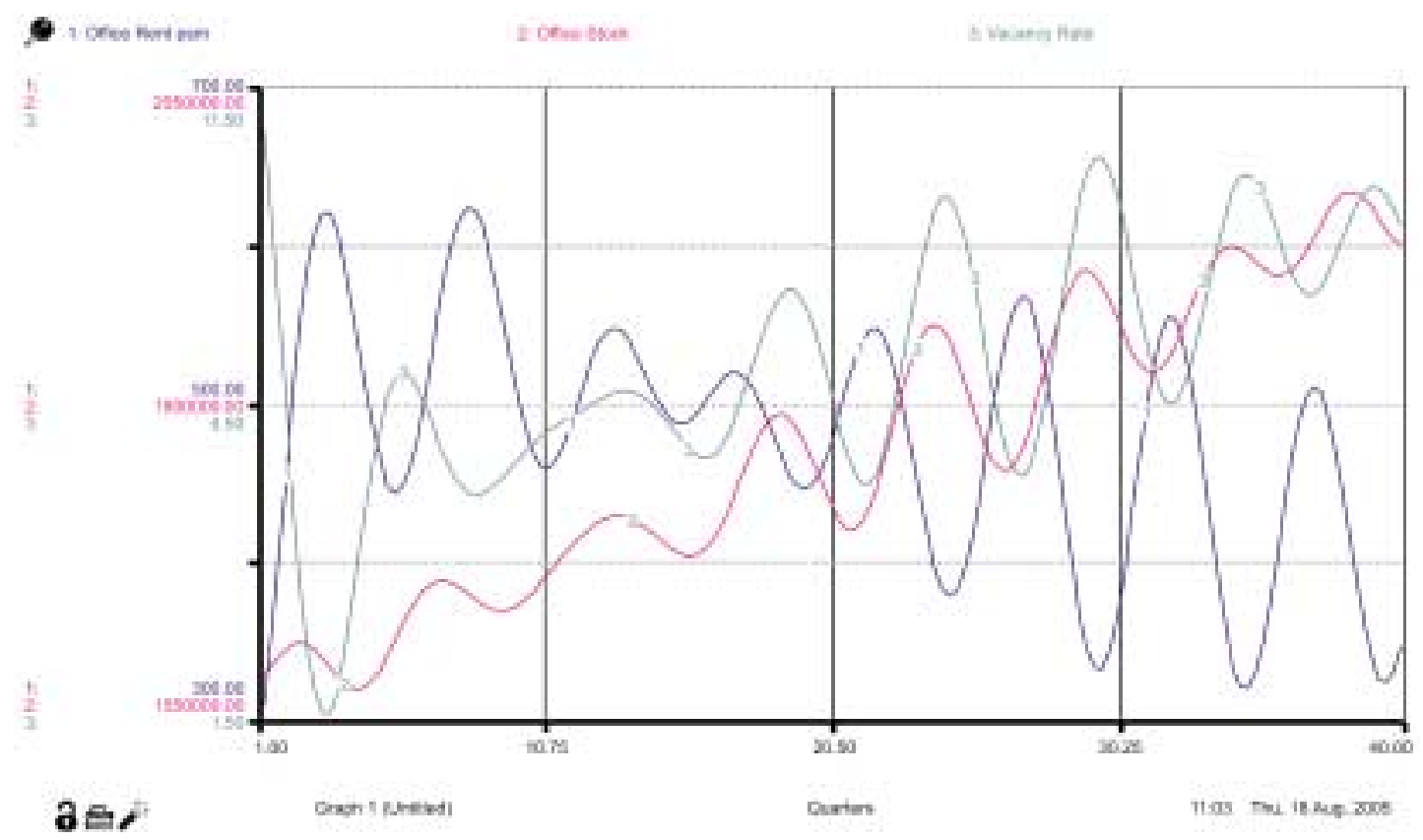

Figure B1. Results of scenario 2

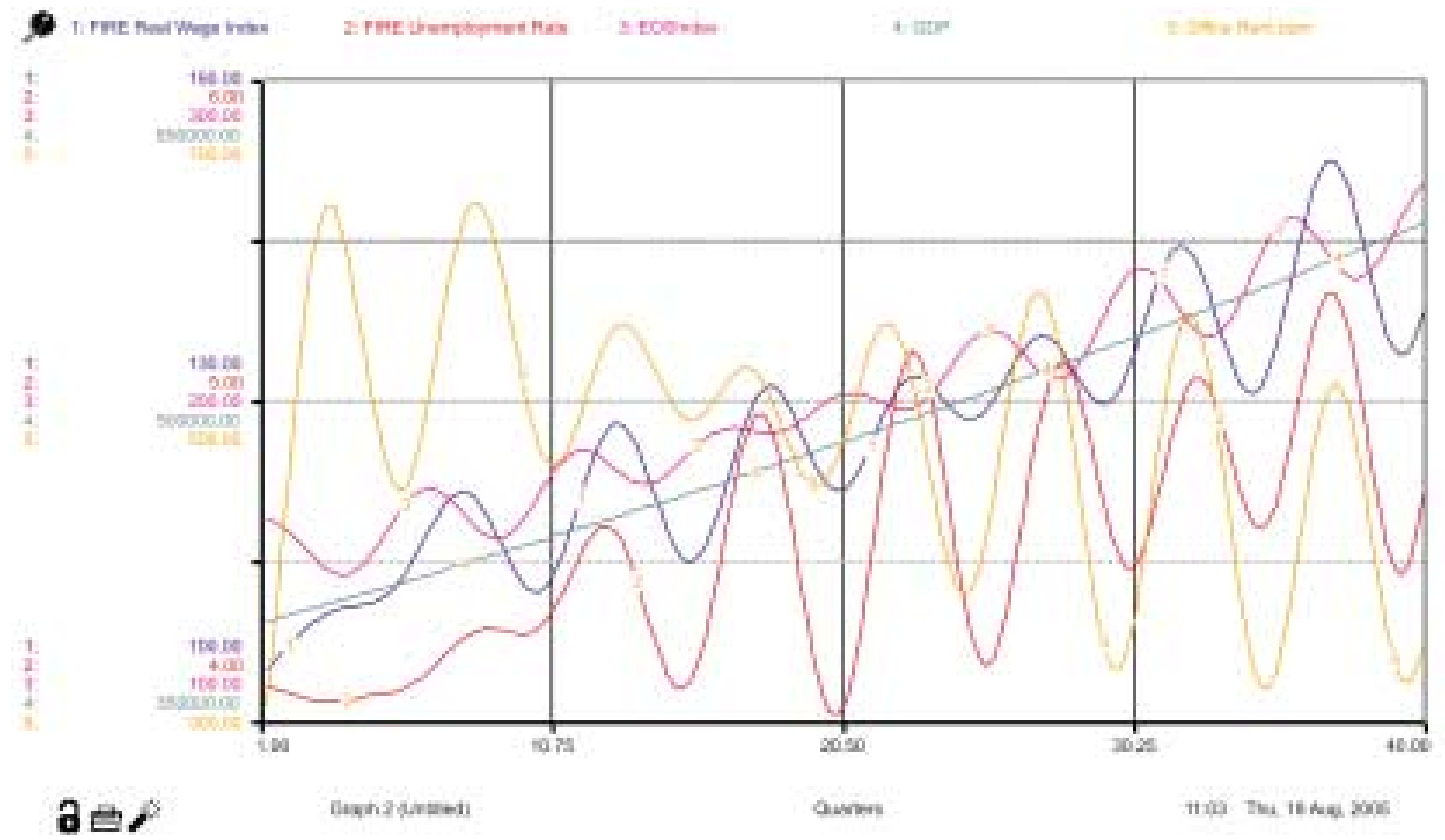

Figure B2. Results of scenario 2 (cont'd) 